\section{Indian view of research}

Economics of Research and Development. By P. M. Chowdhury. Pp. xii + 163. (People's Publishing House: New Delhi, (1973.) Rs18.

AT a time when national expenditure on research in the United Kingdom has declined from the vigorous growth rates of the past two decades to the current provision which barely maintains the present level of activities there is a great deal of thought about the "economics of $\mathrm{R}$ and $\mathrm{D}$ ". $\mathrm{Mr}$ Chowdhury's subject is therefore timely.

The publication, in one volume, of eleven essays chosen by the author from a decade of his writing "about the science of science" does not have the cohesion and logical development of thought which this difficult subject undoubtedly needs. Readers will wish that the author had found the time to condense some of the more generalised essays and to link to them more coherently. He does not communicate ideas very easily and has a rather irritating habit of generalising in the conditional tense, often using technical slang unnecessarily, but the persevering reader is rewarded with nuggets of down-to-earth commonsense and useful ideas.

Those who seek methods for the evaluation of any wide-ranging national programme of research will readily agree that there are "woeful gaps in the data system" and will confirm the difficulties of quantifying research output in terms of the production of scientific papers or of the registration of patents. Few of $\mathrm{Mr}$ Chowdhury's scientific readers are likely to share his confident assertion that the economist is nonetheless able to select research priorities and to assess research programmes.

In the early essays it becomes clear that the author is concerned mainly with industrial research, that is with product and process studies, which are more amenable to short-range planning and assessment than are the endless surprises of the biological world in agricultural research. The part which the author considers chance to play in research is revealing in this context, and most experienced research workers will be startled to read that "it is difficult to obviate the chance factor in research" and that "it has been assumed that the impact of the chance factor in $\mathrm{R}$ and $\mathrm{D}$ sector is more or less on par with that originating in the production process in other sectors". Emphasising the greater role of state involvement in $R$ and $D$ in developing, as compared with developed countries, the author concentrates heavily on the industrial sector and pays too little attention to the predominantly agricultural occupations of his fellow-countrymen. In both the United States and the United Kingdom the state involvement in agricultural $\mathrm{R}$ and $\mathrm{D}$ outweighs that of the private sector.

Mr Chowdhury takes a somewhat unflattering view of scientific research workers. The image of a research manager as one who "assumes the role of an erudite scientist, an efficient organiser or a smart salesman" would startle many senior scientific administrators, but it is uncomfortably near to the truth.

These essays show that India has encountered very much the same underlying problems in the organisation of science as have the more intensively developed countries, for example that "public sector research is structurally separated from industry". Indeed the major part of the reorganisation of British public research on the basis of Lord Rothschild's advice, in three major aspects of biology, those of medicine, agriculture and the natural environment, was to overcome this separation in a highly developed economy. Mr Chowdhury's solutions are similar to those of other countries: of technically efficient scientific advisory committees, with a large measure of independence and a long and stable lease of life. The British Industrial Research Associations would be in full agreement with the author's conclusion that "sponsorship of projects by industries may make them more conscious about programming aspect of the project".

The author concludes that in many developing countries research projects of national importance have failed to receive sufficient momentum for want of really capable personnel for managing them, which summarises effectively some two decades of premature campaigns for "localisation".

The eleven essays offer comments on planning, investment and programming in $R$ and $D$, balance of payments and conservation of foreign exchange, employment of scientific and technical personnel and the perspectives of development.

In a brief but illuminating foreword by Dr B. D. Nag Chaudhuri, Director
General of $R$ and $D$ in the Ministry of Defence, there is set out very clearly the dilemma of Indian scientists, cut off by their higher standard of living from the largely agricultural problems of the population, but uneasy in their uncertain relationships with the allpowerful administration.

These essays will interest all those concerned with developing countries and should be particularly valuable for those who strive to understand the vast complexities of the modern Indian scene. H. C. Pereira

\section{The poetical chemist}

The Wild Uncharted Country. By Deric Bolton. Pp. 48. (Outposts: Walton-onThames, Surrey, 1973.) 75p.

Scientific autobiography in blank verse is a literary genre not often attempted, but this little book shows that it can be done successfully. Although the author's note tells us that the events described are imaginary, the links with real life are close. The protagonist of the poem (he is too unheroic to be called the hero) struggles to qualify at night school; then he has a spell of chemical research at South Kensington; enters industry in the 1930s; engages in "vital war work"; returns to the chemical industry after the war; retires in the $60 \mathrm{~s}$; and is now concerned with environmental and ecological issues, after a lifetime as

An ignorant chemist whose ways of life had run

Within deep narrow channels

His life has flowed like a river, carrying him he knows not where; his career proceeded without self-guidance, seemingly by blind chance. After he retired, the stream broadened out into a flat expanse, letting him see at last the lie of the land around. The poem gains strength from our familiarity with this Neoplatonic imagery of the individual being borne as in a boat down the turbulent stream of life, used directly in Shelley's Alastor and obliquely in Coleridge's Ancient Mariner.

A poem on so mundane a topic depends crucially on the quality of the wording, a challenge which the author meets with a fair degree of success. The writing is careful and, although there are some dull patches, the narrative flows easily and has enough imaginative moments to hold the attention. The chief flaw is that the chemist himself is too much of a puppet, with 